\title{
Robustness of spatial learning in flickering networks
}

\author{
Yuri A Dabaghian ${ }^{1,2^{*}}$, Samir Chowdhury ${ }^{3}$, Andrey Babichev ${ }^{1,2}$, Facundo Mémoli ${ }^{3}$ \\ From 24th Annual Computational Neuroscience Meeting: CNS*2015 \\ Prague, Czech Republic. 18-23 July 2015
}

It is widely accepted that the network of the hippocampal place cells provides a substrate of the "cognitive map" of the environment. However, thousands of hippocampal neurons die every day and the networks formed by these cells constantly change due to various forms of synaptic plasticity. What then explains the remarkable reliability of our spatial memories? We propose a computational approach to answering this question based on a couple of insights. First, we propose that the hippocampal cognitive map is fundamentally topological, i.e., more similar to a subway map than to a topographical city map [1], and hence it is amenable to analysis by topological methods $[2,3]$. We then apply several novel methods from homology theory, to understand how dynamic connections between cells influences the speed and reliability of spatial learning. We simulate the rat's exploratory movements through different environments and study how topological invariants (stable topological features of different experimental environments) arise in a network of simulated neurons with dynamic, "flickering" connectivity. We find that despite transient connectivity the network of place cells produces a stable representation of the topology of the environment.

\section{Acknowledgements}

Work is supported by the NSF grant NSF 1422438 .

\section{Authors' details \\ ${ }^{1}$ Neurology-Pediatrics Department, Baylor College of Medicine, Houston, TX 77030, USA. ${ }^{2}$ Computational and Applied Mathematics, Rice University, Houston, TX, 77005, USA. ${ }^{3}$ Department of Mathematics, Ohio State University, Columbus, $\mathrm{OH}, 43210$, USA.}

Published: 18 December 2015

\footnotetext{
* Correspondence: dabaghia@bcm.edu

${ }^{1}$ Neurology-Pediatrics Department, Baylor College of Medicine, Houston, TX 77030, USA

Full list of author information is available at the end of the article
}

\section{References}

1. Dabaghian $Y$, Brandt $V$, Frank $L$ : Reconceiving the hippocampal map as a topological template. elife 2014, 3:e03476.

2. Arai M, Brandt V, Dabaghian Y: The Effects of Theta Precession on Spatial Learning and Simplicial Complex Dynamics in a Topological Model of the Hippocampal Spatial Map. PLoS Comput Biol 2014, 10(6):e1003651.

3. Dabaghian Y, Mémoli F, Frank L, Carlsson G: A Topological Paradigm for Hippocampal Spatial Map Formation Using Persistent Homology. PLoS Comput Biol 2012, 8(8):e1002581.

doi:10.1186/1471-2202-16-S1-P43

Cite this article as: Dabaghian et al.: Robustness of spatial learning in flickering networks. BMC Neuroscience 2015 16(Suppl 1):P43.
Submit your next manuscript to BioMed Central and take full advantage of:

- Convenient online submission

- Thorough peer review

- No space constraints or color figure charges

- Immediate publication on acceptance

- Inclusion in PubMed, CAS, Scopus and Google Scholar

- Research which is freely available for redistribution

Submit your manuscript at www.biomedcentral.com/submit
C Biomed Central
() Biomed Central

(C) 2015 Dabaghian et al. This is an Open Access article distributed under the terms of the Creative Commons Attribution License (http://creativecommons.org/licenses/by/4.0), which permits unrestricted use, distribution, and reproduction in any medium, provided the original work is properly cited. The Creative Commons Public Domain Dedication waiver (http://creativecommons.org/ publicdomain/zero/1.0/) applies to the data made available in this article, unless otherwise stated. 